\title{
Corruption Eradication within the Protection of the Environment in Indonesia
}

\author{
Sukanda Husin and Hilaire Tegnan ${ }^{1 *}$ \\ International Law Department, Faculty of Law, Andalas University, Padang, Indonesia \\ ${ }^{1}$ Center of Constitutional Studies (PUSaKO), Faculty of Law, Andalas University, Padang, Indonesia \\ $\bowtie$ onlysuccess@rocketmail.com
}

Received March 9, 2017; revised and accepted September 13, 2017

\begin{abstract}
The struggle to eradicate corruption in Indonesia has long been on going yet it seems like the phenomenon is spreading wider and stronger within almost all vital sectors of life on the massive archipelago, including the protection of the environment through legislation and regulations. Aware of this regrettable situation, the government passed Law No. 30/2002 allowing the creation of the Corruption Eradication Commission or Komisi Pemberantasan Korupsi (hereafter referred to as KPK). This law has significantly changed the fight against corruption in Indonesia. Since its creation, the Commission has been hunting down corruptors wherever they are like never before. This paper discusses the effort to prevent corruption in the protection of the environment by providing an overview of the laws and regulations enacted first to protect the environment, then to combat corruption in the process of safeguarding the environment in Indonesia, a country made up of more than seventeen thousand islands where agriculture remains one of the major drives of the economy and social well-being of the Indonesian people. In this paper, several cases of corruption are presented to help explain how corruption takes place in the government's effort to protect the environment.
\end{abstract}

Key words: Corruption, environnemental protection, environnemental law, pollution.

\section{Introduction}

The Indonesian modern environmental law has been developed since the early 1980's through the enactment of Law No. 4/1982 on the Basic Provisions on the Management of the Living Environment (Law No. 4/1982 concerning Basic Provisions on Environmental Protection) which constitutes an umbrella act for environmental protection. The enactment of Law Number 4/1982 followed by that of several environment-related laws such as the Law No 5/990 and the Law No. 24/1992. Being an umbrella legislation, Law No 4/1982 required implementing regulations to produce effective enforcement. In addition to these laws, the Government also passed several important regulations such as the Regulation concerning the Environmental Impact Analysis, the Regulation concerning the Prevention of Water Pollution, etc. (Sukanda Husin, 1997). These regulations, however, are considered insufficient and ineffective to control the pollution and deterioration of the environment (Achmad Santosa, 1994). To overcome the problem, the Government replaced the above mentioned Law 4/1982 with Law No. 23/1997 instead of enforcing the needed regulations (Sukanda Husin, 1997). The enactment of Law No. 23/1997 was also followed by that of several laws and regulations including Law No. 41/1999 on the Forestry, Government Regulation No. 41/1999 on the Mitigation of Air Pollution, Government Regulation No. 27/1999 on Environmental Impact Analysis (EIA) and

*Corresponding Author 
Government Regulation No. 4/2001 on the Mitigation of Damage or Environmental Pollution in relation to Forest and or Land Fires. Law No. 23/1997 was proven unable to manage and control the activities causing deterioration and pollution of the environment due to its leniency toward environmental or other governmental officials who did not comply with environmental laws.

On 3 October 2009, Law No. 23/1997 was repealed and replaced by Law No. 32/2009 (hereafter referred to as Environmental Protection Law) which sets forth criminal sanctions for license issuers including government officials and law enforcement officers who do not comply with the laws and regulations related to environment protection. The debate over the protection of the environment in Indonesia is of an importance considering the inefficiency of the enforcement of environmental laws. Environmental degradation and pollution occur when the environmental or other government officials practice personally economic gains in performing their duties in protecting the environment. In practice, the environmental or other government administrators often issue licenses for business owners who do not fulfill requirements. This often happens because they receive bribery from project owners. Corruptive behaviour may also occur at a compliance monitoring stage whereby the environmental or government officials are actually aware of a breach of environmental law and regulations but remain silent. The same practice also takes place within the law enforcement and the judiciary for the same reasons (Isra et al., 2015).

This paper discusses some corrupt behaviours of law enforcement officers, environmental and government officials that cause environmental degradation and pollution. Finally, this paper suggests some legislative reforms that must be made with regard to the improvement of the existing laws and regulations on environmental protection in Indonesia.

\section{Management and Protection of the Environment}

The Environmental Protection Law is clustered as a functional law (functioneel rechtsgebeid) placing administrative law as the key player in protecting and managing the environment in Indonesia. The portion of administrative law is much broader than civil and criminal law (Rahmadi, 2003). By that design, the role of the government is crucial as it sets up and implements environmental protection standards and issues business licenses so as to prevent the degradation and pollution of the environment. After setting up the environmental protection standards and the issuance of licenses, the government must carry out monitoring to make sure that everybody plays by the rules. In an effort to mitigate the degradation and pollution of the environment, the government is given mandate to impose administrative sanction for non-compliance. Like many other environmental laws in the world, the Environmental Protection Law uses a command and control approach, which means the government must first set up environmental protection quality standards, pollutions standards, degradation standards and licenses (known as a command), and second, it must conduct compliance monitoring and law enforcement (known as control). Based on what has been explained above, the description of the Indonesian environmental protection and management follows the command and control approach. To better understand environmental management and protection, concepts such as pollution prevention; pollution mitigation and restoration; and law enforcement need to be explained.

\section{Pollution Prevention}

The Environmental Protection Act employs several administrative instruments to prevent negative impacts of development on the environment. These include spatial planning, environmental quality standards, environmental impact analysis and licensing (Law Number 32 of 2009 concerning the Protection and Management of the Environment). On the one hand, citizens and legal entities must fulfill all requirements stipulated under the laws and regulations specifying administrative instruments before they can establish and operate their plant and/or business and on the other hand, the Government must examine and verify that the owner of a business has complied with all requirements before granting license.

\section{Spatial Planning}

The first administrative instrument which should be obeyed by everyone or every corporation so as to be able to commence an activity is spatial planning. It functions as a filter for protecting the environment and its ecosystem from negative impacts of development by placing an activity in an area which is specifically designed for such a purpose that will not harm the structure of the area, meaning that the presence of the activity will not jeopardize the lives of humans, animals and other living organisms (Silalahi, 2001). Spatial planning is regulated in the Act Number 26 of 
2007 concerning Spatial Planning. Article 61 of the Act Number 26 of 2007 specifies that to make use of an area for a wanted activity, every person is obliged: (a) to comply with the spatial planning which is already approved by the government; (b) to get a license from the government; (c) to comply with the conditions set out in the license; and to provide accessibility for public in an area designated by law as a public domain.

\section{Environmental Quality Standards}

The second administrative instrument is Environmental Quality Standards. In order to determine a breach in environmental law, there must be a violation of environmental quality standards. According to The Environmental Protection Law, the determination of environmental pollution is measured by environmental quality standards comprised of:
a. water quality standards;
b. waste water quality standards;
c. sea water quality standard;
d. ambient air quality standard;
e. emission standards;
f. interference standards, and
g. development of science and technology standards.

The implementation of environmental quality standards results in a consequence that any person may dispose waste to the environment. However, they must meet environmental quality standards, and receive permission from the minister, governor or regent/mayor in accordance with authority. The disposal of waste to the environment without meeting environmental quality standards and having no permit is considered as a crime though the pollution has not occurred yet.

\section{Environmental Impact Analysis}

The Government Regulation No 27/1999 on Environmental Impact Analysis (EIA) has an important role in preventing pollution. EIA is a detail study concerning positive and negative impacts of any activity. The purpose of the study is to prevent or at least to minimize negative impact of a development and to maximize the positive impact on the environment and its ecosystem (Hardjasoemantri, 2006). The above government regulation is designed to implement Articles 22 and 24 of The Environmental Protection Law which requires EIA to owner or the proponent of any activity which gives rise to large and important impact on the environment. The EIA is a prerequisite condition for deciding whether or not the activity is environmentally feasible. If it is so, the government may issue an environmental license as a prerequisite condition to confer an operational license for commercial operation, such as industrial license, mining concession, etc. EIA is meant to protect the rights of the people residing adjacent to the planned activity. In accordance with The Environmental Protection Law, the people living around the planned project should be well informed about the project. The Government through the Environmental Impact Analysis Commission must involve the people in reviewing the environmental impact analysis initiated by the proponent. The Government must also take into account the complaints of the people in making decisions.

\section{Licensing System}

Licensing system in environmental law is designed to prevent pollution from any activity which has significant and adverse impact on the environment. There are three layers of pollution prevention system, notably Environmental Impact Analysis (EIA), Environmental Permit, and Operational License. The pollution prevention system, first, begins with an obligation of the owner of the activity to carry out EIA. If it is approved, the owner of the activity will have right to get environmental permit. When operational permit is obtained, then the pollution prevention system starts because all the environmental requirements specified in environmental permit are reprinted in the operational license. Based on the Environmental Protection Law, any activity which has significant and adverse impact must have an environmental permit. The environmental permit will only be issued by the Environmental Authority if the EIA of the project is approved by the Environmental Impact Analysis Commission. By this formula, the potential pollution from any activity can be prevented and minimized because the environmental permit contain environmental conditions which should be obeyed by the owner of the activity in order to prevent and clean up the pollution.

The issuance of permit does not guarantee that the activity will not generate pollution. The government's monitoring officer must carry out a spot check routinely to make sure that the owner of the activity complies with all conditions set out in the environmental permit. The Government in preventing larger pollution from the activity may revoke the environmental license if:

1. the documents in a permit application contain legal defects, errors, misuse, and untrue or falsified data;

2. the publication of the permit does not fulfill the requirements as listed in the commission's decision on the environmental feasibility; or 
3. the obligations set forth in Environmental Impact Analysis are not implemented by the owner of the activity.

In the past, when an environmental permit is revoked, the sectorial institutions which issued the operational licenses were reluctant to revoke the operational licenses. Consequently, the activity continued. To prevent this from occurring, The Environmental Protection Law explicitly states that the revocation of environmental permit automatically means the revocation of operational license.

\section{Pollution Mitigation and Restoration}

Once the owner of an activity has an operational license, he/she may start running activity or production. Since some owners of the activity are purely businessoriented people, there is a possibility that they embrace an economic principle - the pollution prevention cost is considered to be a profit reduction, which may generate pollution and cause environmental degradation. To prevent this from occurring, The Environmental Protection Law provides for clauses on environmental pollution mitigation and restoration. In an effort to mitigate environmental degradation and pollution, The Environmental Protection Law requires the owner of the activity to provide the surrounding communities warning information about the environmental pollution and/or damage and to isolate environmental pollution and/or damage right away. Furthermore, the owner of the activity is also obliged to stop the activities causing environmental pollution or damage. With regard to the restoration of the polluted environment, the owner of the activity is obliged to carry out certain efforts to restore the environmental function. The efforts are: (a) to stop the activity causing degradation and pollution of the environment; and (b) to remediate, (c) to rehabilitate and (d) to restore the polluted environment. The details of obligations are regulated in several government regulations and ministerial decrees. For example, to restore the contaminated soil from the oil and gas activity, the Minister of the Environment passed the Decree Number 128/2003, which will be further discussed later on.

\section{Law Enforcement}

The Environmental Protection Law has placed environmental law as a part of administrative law, which means that core function of the environmental law is the management and prevention of the degradation and pollution of the environment. That function is mandated to the government, either at national and provincial levels or local (regional and municipal) level. Therefore, the government must pass laws and regulations to ensure the protection of the environment. The government must, accordingly, make sure that the laws and regulations are obeyed by citizens and legal entities. If the government finds out that citizens and legal entities do not comply with the laws and regulations, the government must impose administrative sanctions. In this context, the use of administrative sanctions is regarded as primum remedium (Hamzah, 2005). If administrative sanctions and civil remedies are unable to stop the non-compliance, the criminal sanctions can be imposed. However, the criminal sanctions can only apply after administrative sanctions and civil remedies are, in fact, unable to halt the deterioration and pollution of the environment. Criminal enforcement is considered as ultimum remedium (Silalahi, 2010).

\section{Administrative Sanctions}

Administrative sanctions play an important role in enforcing environmental law because they have both preventive and curative functions, which are not provided by either criminal sanctions or civil remedies (Husin, 1996). The focus of administrative sanctions is the offence, not the offender like in criminal sanctions. Thus, they can be used as legal tools to prevent and stop the deterioration of the environment, as well as to rehabilitate the environment (Hamzah, 1995). In addition, the procedure of administrative sanctions in comparison with criminal sanctions and civil remedies is not time and money-consuming (Husin, 1996). Unlike criminal sanctions and civil remedies, administrative sanctions can be imposed against the polluter without necessarily going through a court process. The Minister, Governor, and the Head of Region/Mayor for example, are empowered to impose an administrative sanction against the owner of the activity if he/she violates the environmental permit (Article 76(1) of the Law No. 32/2009). The administrative sanctions include: (a) written warning; (b) administrative order; (c) suspension of environmental permit; and (d) revocation of environmental permit (Article 76(2) of the Law No. $32 / 2009$. If a polluter does not or failed to obey the administrative order to clean up the pollutants or to rehabilitate the environment, the government may ask the third party to conduct the clean up and the rehabilitation and the polluter is asked to pay some amount of money spent by the government as cleanup and rehabilitation costs (Article 82(1) of the Law No. 32/2009). 


\section{Civil Enforcement}

Under The Environmental Protection Law, the victims of environmental pollution are entitled to civil remedies. Dispute settlement mechanism is provided for in Articles 85-86. Article 85 enables the parties to an environmental dispute to choose court dispute mechanisms.

There appear two systems of liability introduced by the law, namely liability-based on fault and strict liability. The former requires a plaintiff to prove: (1) that the pollution is caused by an unlawful conduct; (2) that the pollution is the results of a willful misconduct; (3) that the pollution causes monetary injury; and (4) that there is a causal link between the conduct and the injury. The latter is the opposite of the former as it does not require a proof fault. The polluter is strictly liable once the pollution is generated as in Rylands V. Fletcher. In relation to civil remedies, The Environmental Protection Law allows the victims to file lawsuit through a class action. However, the act does not specify the procedures of a class action, for example, the opt in and opt out mechanism and the system of paying compensation to the class members. The procedure of a class is regulated under the Supreme Court Regulation No. 1 of 2002.

\section{Criminal Enforcement}

There appear two kinds of crimes introduced by The Environmental Protection Law, namely generic crimes and specific crimes. Generic crimes refer to the unlawful conducts causing environmental pollution or damage per se. Such unlawful conducts must not relate to the breach of administrative rules (Administrative Independent Crimes) (Koeswadji, 1993; Hamdan, 2000). Accordingly, to prove the guilty mind of the offender does not require the breach of administrative regulations such as licenses, ambient air quality standards, emission standards and so forth. The minimum requirement of this offense is pollution. Specific crimes are defined as conducts, which breach the administrative rules (Administrative Independent Crimes). Specific crime requires the breach of administrative regulations so as to impose criminal sanctions to offender. The Environmental Protection Law has brought about a change of paradigm in Indonesian criminal law, which previously embraced a theory that only individual or natural person can be punished with criminal sanctions while legal person get no criminal punishment as it cannot commit a crime. This is known as societas delinquere non potest (Santosa, 1994). The Environmental Protection Law recognizes corporate crime as stipulated in Articles 116, 117 and 118. By virtue of Article 116, if a criminal action is conducted by legal person, company, association, foundation or any other organization, the criminal liability is increased by one third. The corporate can undergo procedural measures as provided for in Article 119 (Article 46(1) of the Law No. 23/1997). Those procedural measures can be inter alia in the forms of:

a. seizure of profits which were gained through the criminal actions; and/or;

b. closure of all or part of a business; and/or

c. reparation of the consequences of a criminal action; and/or

d. requiring that what was without right neglected be carried out; and/or

e. destroying what was without right neglected; and/ or

f. placing the business under administration for a maximum of three years.

With regard to the enforcement of criminal sanctions in environmental law, one principle should be borne in mind, i.e., subsidiarity principle. This principle outlines that criminal sanctions are subsidiary (ultimum remedium). The primary sanctions in environmental law are administrative sanctions, hence the name primum remedium. This means that the commission of pollution should be dealt with administrative sanctions first. If the use of administrative sanction fails to stop the occurrence of pollution and degradation of environment, then the criminal sanctions may be employed. In this model, criminal law is fully dependent on administrative law. The use of criminal sanctions for a polluter is meant to guarantee that the subject of environmental law comply with the administrative norms (J.C. Oudijk dan D. Schaffmeister, 1994. P. 469-470). This is so because when the subject of environmental law does not comply with the administrative norms, they will face criminal sanctions whose aim is to punish the polluter (Koeswadji, 1993). Criminal sanctions may become a primum remedium only if the pollution and degradation of the environment cause widely detrimental impact and threaten human's life, in which case criminal sanctions can be used without prior recourse to administrative sanctions.

\section{Corruption Vs. Environmental Protection and Management}

\section{Corruption in General}

Corruption has been taking place for a long time in Indonesia and it was anticipated by the enactment of several anti-corruption laws, starting with the State of Emergency Law No. 74/1957 enacted after 
independence (Isra and Agustina, 2015). During Era Reformasi, Law No. 31/1999 was passed and then revised and supplemented with the Law No. $20 / 2001$ on corruption eradication. The enactment of this law has intensified the war on corruption as real criminal sanctions and fines are imposed on corruptors including businessmen and government officials. From the perpetrators point of view, the Corruption Prevention Law extends the subject of law to include business people. The new law is extended to mal-administration even if its deed does not necessarily result in the loss of state's finance. The effort to fight corruption in Indonesia has significantly increased since the People's Consultative Assembly of Republic of Indonesia passed the Decree Number XI/MPR/1998 concerning Clean and Corruption, Collusion, and Nepotism-Free Execution of State's Affairs. This Decree inspired the enactment of the Law No. 28/1999 concerning the same issue and Law No. $31 / 1999$. Article 43 of this law gives a statutory power to the Government to establish a corruption eradication commission. On 27 December 2002 Law 30/2002 concerning Corruption Eradication Commission was passed. The establishment of the Commission was due to decrease in the public's trust in law enforcement agencies. The establishment of the Corruption Eradication Commission and the Corruption Court (Law No. 46/2009 on Court Corruption) has succeeded in levying the quantity of corruption cases brought to the Court.

The success of the Corruption Eradication Commission and the Corruption Court has inspired the Police Department, Attorney Office and Judiciary Body for reforms. They are becoming more active and pre-emptive to fight corruption. Corruption eradication law is being used by Police and Prosecutor to enforce other special laws such as Environmental Protection Law, Forestry Law, Oil and Gas Law, and coal and Mineral Mining Law. Currently, police and prosecutors are trying hard to make the persons and legal entities which pollute and degradation the environment pay for their actions. There have been two environmental cases investigated and brought to the court under the Corruption Eradication Law. For example, bioremediations undertaken by Chevron Pacific Indonesia Limited and its contractors were brought to the Court by the Prosecutor by using provisions under the Corruption Eradication Law. Another example is the beach reclamation project in Tanjung Balai Karimun
Kepri Province whereby the Head of Transportation Office and the director of contractor were charged with corruption by the Police of Tanjung Balai Karimun. In both cases mentioned above, the willful misconducts of the perpetrators were provisions of environmental laws and regulations.

\section{Possibility of Corruption in Pollution Prevention}

As described earlier, there are four administrative instruments used to prevent pollution. These include spatial planning, environmental quality standards, environmental impact analysis and licensing system. This section describes the possibility of corruption occurrence in each of these instruments. Spatial planning is an instrument to prevent environmental conflict of interest; for example, an industry may not be located in a residence area or a mining concession may not be permitted in a national park or other protected forest or area. In reality, there are many cases where a plan is allocated in a residence area and mining concession is given permit to operate in a protected forest; for example, Azirwan, the Secretary of the Regional Government of Kepri (Kepulauan Riau) who wanted to build a complex of Government Offices in a protected area. For that purpose, he needed the approval of both the Minister of Forest and the Parliament. To smooth his plan, Azirwan bribed Al Amin Nur Nasution (a Member of Parliament - Commission IV) with Rp 3 billions. Both Azirwan and Al Amin Nasution were charged with bribery which is prohibited under Article 5 (1) the Corruption Law. Azirwan was awarded 2 years and 6 months imprisonment and fined as much as Rp 100 millions while Al Amin Nasution was sentenced 8 years imprisonment with a fine of Rp 250 millions, and a restitution of $\mathrm{Rp} 2957,000,000$.

This case was not purely environmental corruption but environment-related corruption. Both Azirwan and Al Amin Nasution were prosecuted for breaking Article 5 (1) the Corruption Eradication Law. Notwithstanding, the case was triggered by an effort to get a license which is stipulated in Environmental Protection Law.

The second pollution prevention instrument is environmental quality standards. Corruption can take place at a monitoring stage. Let's say an environmental inspector is bribed not to report a non-compliance of an enterprise after he found out that the said enterprise generates certain waste above the environmental quality standards. The conspiracy of the environmental inspector and the director of the enterprise falls in the category of environmental corruption. The third instrument to prevent pollution is environmental impact 
analysis. Owners or proponents of any activity which has large and important impact on the environment are required to have Environmental Impact Analysis (EIA) by the government. The EIA should be approved by an EIA Commission before the environmental license is issued by Environmental Impact Mitigation Board (BAPEDAL) as argued earlier. Corruption mostly happens in the study of EIA and in the approval process by EIA Commission. Usually, the proponent of the activity bribes the EIA Commissioners and the officers of Environmental Impact Mitigation Board (BAPEDAL). Activities of applying and issuing license to utilize environment and natural resources are the corruption trigger because license means money either for the applicant or for license-issuing officer (Hartoyo, 2011). In this stage, the proponent of the project is asked to pay some amount of money so as to get an operational permit without necessarily getting environmental permit or fulfilling certain requirements. A good example is a beach reclamation case in Karimun in the Province of Kepri. In this case, a company, Jaya Anurya Karimun Ltd., would like to undertake a beach reclamation project from the Government of Karimun. The Government then conferred an operational permit without obliging the company's Director to have EIA and environmental permit. The police are now investigating this case. If found guilty, the Director of Jaya Anurya Karimun Ltd and the Head of the Regional Government can be charged with bribery under the Corruption Eradication Law. The legal ground for this prosecution is breach of the Environmental Protection Law.

\section{Possibility of Corruption in Pollution Mitigation and Restoration}

With regard to the mitigation and restoration of the polluted environment, the owner of the activity is obliged to carry out certain efforts to restore the environmental functions, which includes remediation, rehabilitation and restoration. The details of obligations are regulated in several government regulations and ministerial decrees. For example, to restore the contaminated soil from the oil and gas activity, the Minister of the Environment passes the Decree No. 128/2003 on Technical Procedure and Conditions for Managing Oil Waste and Biologically Contaminated Land by Oil. Article 2 of the Decree No. 128/2003 passed by the Minister of the Environment stipulates every person that produces oil waste and causes land contamination is obliged to manage the waste by bioremediation whose license is granted by the Minister of the Environment. Every owner of oil and gas activity must report their bioremediation project to the Minister of the Environment. Since business is profit-oriented, chances are bribery occurs between the businessman and the monitoring officer along the process. There is also another scenario whereby the owner of the activity conducts bioremediation without a license or the license is overdue. Usually, the proponent of the activity bribes the monitoring officer when they get caught.

Conducting bioremediation without a license is itself against environmental law. Therefore, the owner of the activity and the monitoring officer can be punishable under the Corruption Eradication Law and willful misconduct is a breach of environmental law and regulations. A good example is the bioremediation conducted by Chevron Pacific Indonesia Ltd (CPI) in Duri, Riau Province whereby Bachtiar Abdul Fatah, General Manager Sumatera Light South (SLS) signed a contract of a bioremediation project with Herland Bin Ompo, Managing Director of Sumigita Jaya Ltd. It was discovered that CPI Waste Management License was overdue and that Sumigita Jaya Ltd had no waste management license or was not qualified as a waste management company. Herland Bin Ompo was sentenced to six years of imprisonment and a fine of $\mathrm{Rp}$ 250 million by the Corruption Court on 13 June 2013 and on 17 October 2013, the Corruption Court proved Bachtiar guilty of breaking the Corruption Eradication Law and sentenced him to two years in jail and a fine of Rp 200 millions.

\section{Possibility of Corruption in Spending International Environmental Fund}

The United Nations Framework Convention on Climate Change (UNFCCC) and the Kyoto Protocol are international legal instruments that deal with global climate change. Indonesia has respectively ratified the UNFCCC with the Law No. 6/1994 and the Kyoto Protocol with the Law No. 17/2004, as argued in the outset of this paper. Consequently, UNFCCC and Kyoto Protocol have become the laws in Indonesia. Both the regulations are designed to reduce the concentration of greenhouse gases. One of the reduction mechanisms is the Reducing Emissions from Deforestation and Forest Degradation (REDD+). Under the Clean Development Mechanism, REDD + is decided in COP XII, which declares Bali Action Plan.

REDD+ programme involves developing countries like Indonesia in reducing emissions of carbon dioxide from deforestation and forest degradation. With REDD programme, Indonesia through local governments, non- 
governmental organizations, local/adat community, and individuals may conduct reforestation projects, afforestation and forest conservation to get credits from developed nations who get the carbon credits.

The projects are funded by international environmental fund. The implementation of REDD programme in Indonesia does not give significant contribution to the mitigation effort due to corruptive behaviour (Fuadi, 2010). There are a couple of reasons why corruption occurs. REDD programme which highly depends on honesty may not be successful if the supervision and control are not effective and systematic (BAPPENAS, 2010). The current judgement of the credit is based on the numbers of trees planted at the beginning of the project, not at the end. In practice, many local governments, non-governmental organizations, local/ adat community, and individuals usually pluck the planted trees and transfer or replant them in other project area for financial gain. This deed is considered corruption under the Corruption Eradication Law and has been around for some time and is likely to go on due to legal vacuum. Sadly the Environmental Protection Law does not prohibit this practice.

\section{Possibility of Corruption in Law Enforcement}

There are three kinds of enforcement that are available under the Environmental Protection Law: administrative, civil and criminal enforcements. Since civil enforcement does not involve the use of the executive power, it may not create the possibility of executive corruption. The possibility of corruption in civil enforcement is that the judges are bribed by a defendant or polluter so as to make a verdict to free the polluter from any responsibility (Rahardjo, 2009). In a marine pollution case in Wacopek, Bintan Island, Antam Ltd (PT Antam) was sued by the fishermen to pay compensation for its arsenic waste that polluted the sea and cause the death of all fish. Antam Ltd was found guilty and was fined Rp 2 billions by Tanjung Pinang Court. However, the Court of Appeal in the town of Pekanbaru freed the defendant from all charges. According to the Court of Appeal, the sample of water submitted by the defendant did not contain arsenic, and that the evidence provided by both parties contradicted each other. The plaintiff believed that the decision of the Court of Appeal was unlawful, and its judges were bribed by Antam Ltd. He based his claim on the information he received that two weeks prior to the ruling, all judges and registrar officers of the Appeal Court were invited to join a tennis tournament in Jakarta under the auspices and at expenses of Antam Ltd. Unfortunately, the plaintiff could not give evidence of such claim.

With regard to the administrative and criminal enforcement, corruption can be done by either law enforcers, administrators or by business people. It happens in the whole process of law-inspection, investigation, prosecution, trial and execution. At the inspection stage, corruption involves environmental inspectors and police agents. In every pollution incident, the victims of pollution file an environmental complaint to the Environmental Mitigation Board and Police Office. The environmental inspectors and police agents must find evidence as to whether or not pollution occurred. The environmental inspectors and police agents must ensure that the environmental standard is breached by the polluters. Usually, the polluters employ a "scratch my back and I will scratch yours" approach. The polluters negotiate with the environmental inspectors and police agents so as not to continue the process of law. In return, the environmental inspectors and police agents get the money for closing the case. For example, there have been many environmental complaints filed by Jatam Kaltim, an NGO activist, to the Environmental Mitigation Board and Police Office in East Kalimantan but the process of law failed to run due to corruption.

Corruption is one of the main reasons why environmental cases are not brought to the court. Corruptors get away with their crime by bribing investigators, prosecutors and judges. There is a good example which happened in East Kalimantan where the Managing Director of Kideco Jaya Agung Ltd, a foreign company in Paser Region East Kalimantan was sentenced to one year in jail by the Supreme Court. The execution of the sentence of Managing Director has never been carried out by the attorney office. Jatam Kaltims argued that the execution officer had been bribed by Director of Kideco Jaya Agung Ltd.

\section{Future Environmental Protection}

\section{Environmental Law}

The enforcement of the Corruption Eradication Law in environmental cases is not without handicap. The first handicap is due to the principle of lex specialis derogaat legi genaralli meaning that the rules of special law are subordinate to general ones (Muchsin, 2006). Both Environmental Protection and the Anti-Corruption laws are lex specialis of the Indonesian Penal Code. Should a case of environmental violation involve corruption, one might ask which law is to apply, giving rise to the issue of overlapping regulations. The second handicap relates 
to the principle of subsidiarity in criminal law. This principle puts criminal law secondary in the enforcement of law, especially functional law like environmental law. Therefore, the breach of environmental law should first be tackled with administrative sanctions outlined in the environmental law, i.e., the Environmental Protection Law. The law enforcement officer has no power to use criminal sanctions, either set forth in the Environmental Protection Law or in the Corruption Eradication Law.

The last handicap lies in the phrase of Article 14 of the Corruption Eradication Law which specifies that the provisions of the Corruption Eradication Law cannot be used against anybody that breaches another law (such as the Environmental Law) and does not refer to the act as corruption. Similarly, none of the provisions of the Environmental Protection Law stipulates that the breach of environmental regulations is a corruption. To prevent corruption in the protection and management of the environment, the Environmental Protection Law should be revised in a way that supports the implementation of the Corruption Eradication Law.

The first thing to do is strengthen the subsidiarity principle which is only mentioned in the Preamble of the Environmental Protection Law. Environmental Protection Law should specify an exception for implementing ultimum remedium principle, by inserting a provision to allow criminal law to become primum remedium. The exception should also specify that if the breach of environmental standard involves corruption, criminal law can become primum remedium. The second thing to do is to accommodate the ruling of Article 14 of the Corruption Eradication Law. A new provision should be inserted into Chapter XV of the Environmental Protection Law. This new article must clearly specify that the breach of environmental law and regulations which involves bribery or any illegal payment should be qualified as corruption. It should also solve the problem of lex specialis derogaat legi generally principle by ruling which law is to prevail over a case of corruption in protecting and managing the environment. To prevent the corruption that happens in utilizing the international fund under the REDD+ programme, the Environmental Protection Law should be revised so as to rule the deviation of utilization of international fund as a crime (corruption).

\section{Conclusion}

To prevent environmental pollution in Indonesia, Law No. 32/2009 on environmental protection sets several requirements that must be met before the acquisition of a license and the commencement of any environment-related activity. Those requirements deal with spatial planning, environmental quality standards, environmental impact analysis and licensing. However, despite the existence of such mechanisms along with numerous laws and regulations on both the protection of the environment and the eradication of corruption, pollution and many other forms of environmental degradation still occur in Indonesia. The struggle to eradicate corruption in the protection of the environment is hindered by various principles such as subsidiarity in criminal law and lex specialis derogaat legi genaralli which means that rules of special laws are subordinate to those of a general law. In the case of Indonesia, both Environmental Protection Law and the Anti-Corruption Law are lex specialis of the Penal Code, which raises the question as to which law to use when there is a breach of environmental law.

There is a need to reform the environment law by strengthening the subsidiarity principle, and by revising Article 14 of the Corruption Eradication Law. The Environmental Protection Law must accommodate the ruling of Article 14 of the Corruption Eradication Law by classifying any breach of environmental law involving bribery or any illegal payment as an act of corruption. The new provision should also solve the lex specialis derogaat legi genaralli problem, and categorize the misuse of international funds such as the REDD+ programme as corruption, therefore a crime. Fuller (1964) is wrong when he argues that the frequent change in law is not good and results in legal certainty. As corruptive behaviours as well as societies evolve, laws must be revised in order to meet the new realities and challenges. The revision of both Environmental Protection and Corruption Prevention laws is meant for the benefit of good and effective law enforcement in the field of environmental management and protection.

\section{References}

\section{Articles and Books}

BAPPENAS (2010). Rancangan strategi Nasional REDD+, Revisi Tanggal 18 November 2010, UN REDD Programme, Indonesia.

Fuady, Munir (2010). Dinamika Teori Hukum. Cetakan Kedua, Ghalia Indonesia, Bogor.

Fuller, Lon L. (1964). The Morality of Law. Revised Edition, Yale University Press, the United States of America. 
Hamdan, M. (2000). Tindak Pidana Pencemaran Lingkungan Hidup (Environmental Offences). Penerbit CV Mandar Maju, Bandung.

Hamzah, Andi (2005). Penegakan Hukum Lingkungan. Cetakan Pertama, Penerbit Sinar Grafika, Jakarta.

Hamzah, Andi (1995). Penegakan Hukum Lingkungan. Penerbit Arikha Media Cipta, Jakarta.

Hardjasoemantri, Koesnadi (2006). Hukum Tata Lingkungan, edisi Keenam Gadjah Mada University Press, Yogyakarta.

Hartoyo, Dwi (2011). Panduan Audit Investigatif Korupsi di Bidang Kehutanan. Center for International Forestry Research (CIFOR), Bogor Barat, Indonesia.

Michael Faure-Gunter Heine (2007). Environmental, Criminal Law in the European Union. Oxford University Press. doi. org/10.1093/jel/eq1045

Husin, Sukanda (2009). Penegakan Hukum Lingkungan Indonesia. Sinar Grafika, Jakarta.

Husin, Sukanda (1997). Perubahan Mendasar dalam RUU Lingkungan Hidup (Suatu Studi Komparatif). YUSTISIA (Jurnal Hukum Universitas Sebelas Maret), 6(4).

Isra, Saldi and Shinta, Agustina (2015). Obstruction of Justice, Tindak Pidana Menghalangi Process Hukum Dalam Upaya Pemberantasan Korupsi. Themis Book, Jakarta.

Koeswadji, Hadiati, Hermien (1993). Hukum Pidana Lingkungan. Penerbit PT Citra Aditya Bakti, Bandung.

Muchsin, Ikhtisar (2006). Ilmu Hukum. Badan Penerbit Iblam, Jakarta.

Rahardjo, Satjipto (2009). Hukum Progresif: Sebuah Sintesa Hukum Indonesia. Genta Publishing, Yogyakarta.

Rahmadi, Takdir (2003). Hukum Pengelolaan Bahan Berbahaya dan Beracun. Airlangga University Press, Surabaya.

Santosa, Mas Achmad (1994). Penegakan Hukum Lingkungan: Kajian Praktek dan Gagasan Pembaruan. Jurnal Hukum Lingkungan, Jakarta. Indonesia Center for Environmental Law (ICEL). II(1).

Silalahi, M. Daud (2010). Amdal: Dalam Sistem Hukum Lingkungan di Indonesia. PT. Suara Harapan Bangsa, Bandung.

Silalahi, M. Daud (2001). Hukum Lingkungan: Dalam Sistem Penegakan Hukum Lingkungan Indonesia. Penerbit Alumni, Bandung.

\section{Laws and Regulations}

Law No. 32/2009 on Environmental Protection and Management, National Gazette No. 140/2009 and
Supplement to the Indonesian National Gazette No. $5059 / 2009$.

Law No. 46/2009 on Corruption Court, Indonesian National Gazette No. 155/2009 and Supplement to the Indonesian National Gazette No. 5074/2009.

Law No. 17/2004 on Kyoto Protocol on Climate Change, Indonesian National Gazette No. 72/2004 and the Supplement to the Indonesian National Gazette No. $4403 / 2004$.

Law No. 30/2002 on the Corruption Eradication Commission and Indonesian National Gazette No. 137/2002.

Law No. 20/2001 on the Revision of Law No. 31/1999 on Corruption Eradication, Indonesian National Gazette No. $134 / 2001$ and Supplement to the Indonesian National Gazette No. 4150/2001.

Law No. 31/1999 on Corruption Eradication, Indonesian National Gazette No. 140/1999 and Supplement to the Indonesian National Gazette No. 3874/1999

Law No. 28/1999 on Clean and Corruption, Collusion, and Nepotism-Free Execution of State's Affairs, Indonesian National Gazette No. 75/1999 and Supplement to the Indonesian National Gazette No. 3851/1999.

Law No. 41/1999 on Forestry and the National Gazette No. $167 / 1999$.

Law No. 4/1982 on the Basic Provisions on Environmental Protection and National Gazette No. 12/1982.

Law No. 6/1994 on the United Nations Framework Convention on Climate Change.

Law No. 24/1992 on Spatial Planning, National Gazette No. $115 / 1992$.

Law No. 5/1990 on the Conservation of Biological Resources and their Ecosystem, National Gazette No. 49/1990 and Supplement to the National Gazette of the Republic of Indonesia No. 3419/1990.

Law No. 3/1971 on Corruption Eradication, Indonesian National Gazette No. 19/1971 and Supplement to the Indonesian National Gazette No. 2958.

Government Regulation No. 41/1999 on the Mitigation of Air Pollution, National Gazette No. 86/1999.

Government Regulation No. 4/2001 on the Mitigation of damage or environmental pollution in Relation with Forest and or Land Fires.

Government Regulation No. 27/1999 on Environmental Impact Analysis, National Gazette No. 59/1999.

Framework Convention on Climate Change, reprinted in 31 International Legal Materials 849 (1992). 